\title{
СОЦІОЛНВІСТИКА
}

УДК $81 ' 27+246.2+276.3-053.5$

\section{МАСОВЕ ОПИТУВАННЯ \\ ЯК ОСНОВНИЙ МЕТОД ДІАГНОСТУВАННЯ МОВНОЇ СИТУАЦІЇ В УКРАЇНСЬКІЙ ШКІЛЬНІЙ ОСВІТІ}

\author{
ДАНИЛЕВСЬКА О. М.
}

\author{
кандидат філологічних наук, \\ старший науковий співробітник \\ Інститут украӥнської мови НАН України \\ od3556261@gmail.com
}

\begin{abstract}
У статті обгрунтовано актуальність дослідження мовної ситуації в українській шкільній освіті за методикою масового опитування, схарактеризовано систему запитань для соціолінгвістичного зрізу в межах Проекту № 62700395 Фонду Фольксваген “Біта мультилінгвізм: між інтенсифікацією та розв’язанням конфлікту. Етнолінгвістичні конфлікти, мовна політика і контактні ситуації в пострадянських Україні і Росії”в аспекті якісних та оцінних параметрів мовної ситуації. Уточнено соціолінгвістичні критерії, на підставі яких зроблено висновок про зміни в мовній ситуації у сфері шкільної освіти в період від 2006 по 2017 р., зокрема простежено динаміку успадкованих від радянської епохи регіональних відмінностей та кількісних виявів деформації за лінією "місто село”. Схарактеризовано систему запитань, спрямованих на збір даних стосовно оцінки суспільством мовної політики у сфері шкільної освіти.

Ключові слова: соціолінгвістика, мовна ситуація у сфері освіти, методи соціолінгвістичних досліджень, масове опитування, мовна політика.

\section{MASS POLL AS THE MAIN LANGUAGE SITUATION DIAGNOSING METHOD IN UKRAINIAN SCHOOLING}

\author{
DANYLEVSKA Oksana Mykolayivna \\ Candidate of Sciences (Philology), Senior Research Fellow \\ Institute of Ukrainian Language, \\ National Academy of Sciences of Ukraine,
} od3556261@gmail.com
\end{abstract}

Introduction. The need to involve questions concerning quality and valuation parameters of linguistic situation in the material collection is caused by diglossic nature of bilingualism in schools in most parts of Ukraine, which is evident in the areas of the language use: Ukrainian in class, and Russian - during the breaks and after school activities. The language situation in a particular school, regardless of the status of language teaching, due to the configuration of the language situation in the region, which, however, is not included in statistical reports. That is shown in the survey carried out within the framework of Project No. 62700395 of the Volkswagen Foundation "Bi- and Multilingualism: between intensification and conflict resolution. Ethnolinguistic conflicts, linguistic politics and contact situations in post-Soviet Ukraine and Russia”, a system of questions was proposed concerning the real linguistic situation (perception of the linguistic environment, its assessment by the respondents) and its desirable development, that is, in the aspect of language policy in the field of education.

Purpose. The paper focuses on the relevance of the language situation study in Ukrainian schooling using the mass poll methodology, due to mismatch of statistical data on the functioning of Ukrainian as the state language and the real facts of the language use in the secondary schools. 
Methods. The research is grounded on the methods of sociolinguistics, that is quantitative and qualitative analysis applying survey fieldwork and language boundary/difference perception.

Results. The article specifies the sociolinguistic criteria on the basis of which the conclusion about changes in the linguistic situation in the field of school education in the period from 2006 to 2017 is made, in particular the dynamics of the regional differences and quantitative deformation inherited from the Soviet era in the "city - village" aspect are traced. In particular, questions aimed at data collection on the assessment of the society's linguistic situation in the field of education were thoroughly analyzed. These questions made it possible to trace changes in linguistic behavior of respondents depending on the sphere of communication. Comparison of responses in the regional dimension revealed the heterogeneity of the language situation in school education by region, and the analysis of the responses of different population centers residents allowed to trace trends in overcoming the unevenness of linguistic development in the state in the "city - village" aspect. Providing respondents with questions that envisaged the assessment of possible language policy in the field of school education, we sought to determine whether this assessment depends on the peculiarities of the linguistic situation in the region, how common the stereotypical representations about the desired language education are, or whether the general political situation in the state affects perception and an assessment of the linguistic environment of educational institutions by the speakers. A separate question dealt with the prospects of bilingual education in Ukraine.

Conclusions. The compulsory comparison of the results of several sociolinguistic polls was emphasized to conclude on changes in the language guidelines for the desired perspectives of language education and language policy measures in the field of school education.

Keywords: sociolinguistics, linguistic situation in the sphere of education, methods of sociolinguistic research, mass poll, linguistic politics

Формулювання проблеми та обгрунтування актуальності їі розв'язання. Про актуальність проблем функціонування української мови у сфері шкільної освіти свідчить гостра дискусія 3 приводу статті 7 “Мова освіти” нового закону про освіту (№ 2145-VIII), ухваленого 5 вересня 2017 р. Експертне середовище й громадськість, представники різних політичних таборів, обстоюючи свою позицію щодо функціонування мов у загальноосвітніх навчальних закладах, покликалися на власні спостереження, особистий досвід, публікації в ЗМІ, історичні факти тощо, але не на дані соціологічних досліджень, суху мову цифр, бо виявилося, що таких просто немає. Найслабшими в резонансних обговореннях виглядали аргументи представників дипломатичного корпусу України, а також чиновників Міністерства освіти, яким довелося пояснювати впровадження норм з посилення позицій української мови як державної в освіті апеляціями до міжнародного досвіду, хоч більш виваженими й набагато переконливішими були б, безперечно, оцінки реальної мовної ситуації в українській освіті. Але через те що спеціального дослідження мовної ситуації в загальноосвітніх навчальних закладах в Україні досі проведено не було, багатьом здалося, що держава Україна вдається до волюнтаризму, який загрожує звуженням мовних прав великій кількості громадян.

На жаль, суспільна актуальність мовного питання в Україні не спричинила розширення емпіричної основи вивчення мовної ситуації. В абсолютній більшості робіт, - констатують соціологи, - мовну ситуацію аналізують на дуже обмеженому колі показників. Приміром, у щорічних моніторингових дослідженнях Інституту соціології НАН України використовують лише два показники: 1) рідна мова (без визначення, що розуміють під “рідною мовою”); 2) мова спілкування в родині (вдома) (Якою мовою (мовами) Ви переважно спілкуєтесь у Вашій родині (вдома)? - із варіантами відповіді: “переважно українською", “переважно російською”, "і українською, і російською, залежно від обставин”, “іншою мовою”). Саме тому дослідження мовної ситуації у сфері освіти, зокрема в середніх школах, за методикою масового опитування $€$ надзвичайно актуальним.

Мета статті - обгрунтувати ефективність масового опитування в діагностуванні мовної ситуації в українській шкільній освіті. 
Виклад основного матеріалу дослідження. Мовну ситуацію в українській шкільній освіті визначає формальна та фактична взаємодія української мови як державної з російською та іншими мовами національних меншин, а також мов, які вивчають як іноземні. Проте найістотніше значення для характеристики мовної ситуації в окресленій царині має функціонування в закладах освіти української мови як державної та російської як мови неформального спілкування великої кількості учасників навчального процесу. Таку конфігурацію мовної ситуації у сфері освіти в незалежній Україні визначають кілька чинників.

Перший чинник - це загальнодержавна мовна ситуація, успадкована від імперської та радянської епох. Формальна зміна статусу шкіл після проголошення незалежності України лише посилила успадковану від СРСР деформацію, адже система освіти в СРСР була дієвим механізмом офіційної мовної політики, яка на українських теренах мала на меті цілковите зросійщення й асиміляцію українців. Попри офіційність державного статусу української мови в освіті в незалежній Україні й переконливе формальне домінування (статистичні показники кількості шкіл та класів з українською мовою навчання та кількості учнів, які на підставі цих показників отримують освіту українською мовою) для мовної ситуації в освіті і сьогодні характерна нерівномірність за регіонами та деформація за лінією “місто - село”, що дає підстави для висновку про невідповідність декларацій і реального стану застосування державної української мови в шкільній освіті.

Другий чинник - аморфність державної мовної політики, виявом чого була цілковита відірваність іï заходів упродовж десятиліть від реальної мовної ситуації в освіті: ці заходи зводилися здебільшого до декларування загальних принципів забезпечення мовних прав, проте не мали на меті впливати на мовну поведінку мешканців великих міст, стереотипи якої сформувалися кілька поколінь тому (Тараненко, 2009). Тож попри декларації і гасла, ініційовані владою заходи з розширення функціонування української мови у сфері освіти за роки незалежності не зменшили масштабів зросійщення, а в деяких сферах суспільного життя, як наголошує Л. Масенко, негативні процеси ще й посилилися (Масенко, 2016). На підставі зазначеного соціолінгвісти роблять висновок про неефективність державної мовної політики загалом і системи мовної освіти зокрема. Прикметою українського мовного буття є й та обставина, що експертне середовище, зокрема мовознавці, до кола наукових інтересів яких належать проблеми функціонування мови в суспільстві та аналіз мовної політики, майже впродовж усієї історії незалежної України перебували у своєрідній опозиції до державних органів, відповідальних за мовне регулювання. Має прихильників думка, що невизначеність мовної політики незалежної України зумовлена тим, що стратегічну мету державного розвитку олігархічно-владна верхівка завжди приховувала від суспільства, що 3 усією очевидністю відкрилося у 2013-2014 pр. у зв'язку з російською агресією. Це дає підстави говорити про причини замовчування реальних мовних проблем і фактичного продовження політики зросійщення України методами “добровільної відмови”, започаткованими в СРСР в 70-ті роки минулого століття (Марусик, 2017).

I, нарешті, третій чинник - це посттоталітарний характер системи освіти в Україні, що зумовлює, з одного боку, їі формалізм, відірваність від потреб учнів і батьків, а з іншого боку - закритість, традиційність, слабку здатність до оновлення, що спричиняє колективний опір освітньої бюрократії формальним заходам мовної політики, які суперечать звичкам і стереотипам цієї бюрократії.

Вплив цих чинників не був однаковим упродовж історії незалежної України. Зокрема, у перші роки йшлося про ширше використання української мови в освіті відповідно до статусу державної, який було проголошено в 1989 р. законом “Про мови в Українській РСР”, що виявлялося передусім у збільшенні кількості шкіл та класів з українською мовою навчання відповідно до статистичної кількості українців у державі, адже в 1991 р. українською мовою 
в Україні навчалося тільки 49,3 \% учнів ${ }^{1}$ (до 2005 ця кількість зросла до $77 \%$, а сьогодні становить $89,7 \%$ ). Але оскільки зміна мови навчального процесу в багатьох випадках була формальною і не призводила до змін викладацького складу в навчальних закладах, не поширювалася вона й на позаурочні заходи, то часто виявлялася в суто формальному вживанні мови на уроці та в тих підручниках, якими користувалися учні: якщо до переведення школи або класу на українську мову навчання діти користувалися підручниками російською мовою, то зі зміною мови викладання стали користуватися підручниками українською мовою*. Що ж до вчителів, то зміна мови навчання в конкретній школі цілковито залежала від їхньої здатності викладати предмет українською мовою. Тому реальна українізація загальноосвітніх навчальних закладів природно відбувалася в українськомовних регіонах та населених пунктах, де українська була більш поширеною в повсякденні, - містечках і селах. Що ж до Сходу та Півдня, то в цих регіонах учителі-предметники часто продовжували викладати матеріал російською мовою або користувалися українською на дуже низькому рівні, удаючись до мовного змішування чи постійного перемикання кодів. Типовим є приклад уроку зарубіжної літератури в 5-му класі, який довелося спостерігати в київській школі на початку 2000 р.: учителька постійно зверталася до дітей російською мовою, переходячи на українську тільки для фіксації етапів уроку або певних форм роботи, пор.: рос. "Итак, начнем урок”, “Будьте внимательны”", “Это очень интересная тема", "Вы любите читать сказки?", "Запишите в тетрадях дату”, "Не выкрикиваем с места, когда есть, что сказать, поднимаем руку”; укр. "Тема уроку Міфи народів світу", "Прочитаємо в підручнику”, "Відповідаємо на запитання до тексту”. Про незбіжність висновків на підставі офіційної статистики про функціонування української мови в школах і спостережень реального мовного середовища свідчить і такий приклад: "Перевела дітей (7-й клас) через зміну місия проживання в іншу гімназію. Заклад спеціально шукала, щоб була гімназія, бо діти до иього навчалися в украӥнськомовній гімназії. Гімназія заявлена як украӥнськомовна (поряд є і російськомовна школа), тому зупинили вибір на иій гімназії. Великим здивуванням було те, що вчителі уроків фізики, хімії та біології пояснювали тему російською мовою (підручники - украӥнською).

До слова, усі діти в класі розмовляють теж російською, що не дивно, адже це Дніпро. Та й наші попередні однокласники теж спілкувалися російською. Але тут не лише спілкування, а й подання інформації вчителем було російським. Діти мої сказали про ие класній керівничщі. Вона пообіияла з'ясувати і розв'язати ию ситуаиію. Наступні уроки біології та хімії були українською. А от фізика лишилася без змін ...” (Із допису матері школярів з Дніпра в мережі Фейсбук).

Варто наголосити, що якихось заохочень для вчителів або механізмів контролю за ними в дотриманні мовного режиму в Україні ніколи не було, що й дає підстави говорити про формальність заходів з українізації освіти. Саме тому реальний стан мовного середовища навчальних закладів залежить від мовної ситуації в регіоні, віддзеркалюючи іiі.

Упродовж перших десяти років незалежності вживання української і російської мов у навчальних закладах у російськомовних регіонах стереотипізувалося такою мірою, що призвело до стійкого розподілу мов за сферами вживання: українську (кращої або гіршої якості) вживали на уроках, а російську - у неформальному спілкуванні на перервах та в позаурочних заходах, пор.: 1) “Катастрофічну ситуацію маємо в київських школах... Таке враження, що украӥнська мова в закладах середньої освіти - ие така собі гра, у яку прийнятло бавитися під час уроків. На перервах і шкколярі, і вчителі спілкуються російською, а показове смикання - "якою мовою ти говориш, в якій школі навчаєшся?" - не більше, як непотрібний ритуал, що всім набрид" (Юлія Кропив’янська, “Мовна ситуація Києва”, 2008 р.) (Масенко, 2010, с. 200); 2) “Після сьомого класу я вступила до Полтавського міського лічею - найпрестижнішої, як вважалося, школи міста. Офіційно це був иілком украӥнський заклад: тут навіть не було уроків російської 
мови. Проте “мовою міжнаціонального спілкування” (мало не в прямому значенні-адже в ліцеї навчалися і вірмени, і росіяни, і представники інших національностей) була російська, якою на перервах спілкувалися майже всі. Виняток становили тільки учні з приміської зони, які говорили переважно суржиком. Узагалі в полтавських школах і вчителі (крім тих, щуо викладають украӥнську мову чи літературу) часто в позакласному спілкуванні, а то й на уроках, переходять на російську. Навіть у де-юре украӥнському ліиеё деякі предмети в нас читали російською (з волі вчителів, бо їм було, як вони казали, важко говорити украӥнською). В інших школах y “найпрестижніших”, найуспішніших класах учні між собою спілкуються винятково російською” (Ольга Цимбал, “Мовна ситуація в Полтаві”, 2008 р.) (Масенко, 2010, с. 210); 3) “Він [батько ]повідомив, щзо його украӥномовна дитина почувається іноземием у школі з украӥнською мовою навчання... бо усі навколо - $i$ діти, $і$ вчителі - говорять у позаурочний час російською, більше того, коли є вибір: чи піти в планетарій на російськомовну програму ( с там чомусь така) чи на украӥнськомовну - викладачі, які організовують такі походи завжди зупиняються на російськомовній. У результаті, дитина каже, щзо було цікаво, але деяких слів вона не зрозуміла, бо програма була іноземною мовою” (Івахнюк, 2017).

Окремо варто наголосити на тій ролі, яку для розвитку мовної ситуації в шкільній освіті відіграв посттоталітарний характер останньої. Залишкові явища тоталітарної педагогіки сприяли утвердженню в школах подвійних стандартів, нещирості учасників навчального процесу, несприйнятті формальних правил школярами-підлітками. Показовою у зв'язку з цим $€$ заувага одного з учнів Українського гуманітарного ліцею (навчального закладу, створеного під егідою Київського національного університету імені Тараса Шевченка), відомого жорстким дотриманням мовного режиму. Так от у стінах цього закладу серед учнів також поширена двомовна поведінка - як заперечення аж надто суворих, з одного боку, і формальних з іншого шкільних правил.

Наведені приклади - це типові вияви мовної ситуації в українській шкільній освіті, які, щоправда, залишаються не обрахованими офіційною статистикою, основним критерієм якої $\epsilon$ кількість учнів, залучених до навчання українською мовою. Саме тому масове соціолінгвістичне дослідження, яке мало на меті з'ясувати реальну мовну ситуацію в Україні, передбачало й низку запитань, які стосувалися функціонування української мови в загальноосвітніх навчальних закладах. Мета пропонованої статті - проаналізувати ці запитання, а також розкрити загальні напрями аналізу отриманих даних.

Опитування, здійснене в межах Проекту № 62700395 Фонду Фольксваген “Біта мультилінгвізм: між інтенсифікацією та розв’ язанням конфлікту. Етнолінгвістичні конфлікти, мовна політика і контактні ситуації в пострадянських Україні і Росії”, проведене з 2 по 10 лютого 2017 р. в 24 територіально-адміністративних одиницях України та в м. Києві методом індивідуального інтерв”ю “віч-на-віч” за місцем проживання респондента. У дослідженні брали участь 2007 респондентів, 3 них 905 - чоловіки (45,1\% від загального числа опитаних), 1102 - жінки (54,9 \% від загального числа опитаних). В опитуванні пропорційно представлені всі регіони України, крім Криму, та територій, не контрольованих українською владою, у Донецькій та Луганській областях. Під час дослідження для забезпечення репрезентативності отриманих даних було проведено інтерв'ю серед усіх вікових груп у структурі загального населення України. Варто наголосити, що представники двох вікових груп - 18 - 29 р. (10,5 \% від загальної кількості інформантів) і 30 - 39 р. (9,4 \%) - це ті учасники, які завершували чи отримували загальну середню освіту вже в незалежній Україні, тож їхні відповіді стосовно мовної ситуації в загальноосвітніх навчальних закладах грунтуються на власному досвіді.

Опрацювання результатів дослідження передбачало аналіз у регіональному вимірі. Задля релевантності порівняння з результатами попереднього опитування (за програмою INTAS) збережено розподіл областей на 5 регіонів, а саме: Захід (Волинська, Рівненська, Львівська, 
Івано-Франківська, Тернопільська, Чернівецька, Закарпатська області); Центр (Вінницька, Хмельницька, Кіровоградська, Черкаська, Полтавська області); Північ (Київська, Чернігівська, Житомирська, Сумська області, м. Київ); Схід (Дніпропетровська, Харківська, Запорізька, Донецька, Луганська області); Південь (Миколаївська, Одеська, Херсонська області). Щоправда, через утрату частини Донецької і Луганської областей та Криму не надаються для порівняння Схід і Південь. Тому порівнювали тільки Захід, Центр та Північ.

Дослідження передбачало також проведення бесід у фокус-групах - по дві з респондентами різних вікових категорій (молодша, 18 - 39 р., і старша, 40 - 60+ р.) у чотирьох містах: Києві, Львові, Харкові та Одесі.

Збір даних щодо функціонування української та інших мов у загальноосвітніх навчальних закладах здійснено у двох аспектах: реальної мовної ситуації (сприймання мовного середовища, його оцінка респондентами) та ії бажаного розвитку, тобто в аспекті мовної політики у сфері освіти.

Мовної ситуації у сфері освіти загалом стосувалося десять запитань анкети. Запитання A5 Скільки людей, на Вашу думку, розмовляс украӥнською мовою в населеному пункті, де Ви мешкаєте, у школах? (варіанти відповіді: майже ніхто, значно менше половини, близько половини, значно більше половини, майже всі, важко відповісти) давало можливість з'ясувати, 3 одного боку, які сфери функціонування мови, за оцінками респондентів, є найбільшою мірою українізованими, а з іншого - якою мірою середовище шкіл, яке має слугувати основним каналом зміцнення позицій української мови як державної, слугує інструментом мовної політики. Оскільки серед сфер функціонування мови в цьому запитанні, окрім офіційних (державні заклади, загальноосвітні школи, заклади вищої освіти) наведено й сфери неофіційної комунікації (формальної - транспорт, сфера послуг, незнайомі співрозмовники; неформальна - друзі, родина), то отримані результати дали змогу простежити зміни в мовній поведінці респондентів залежно від сфери комунікації. Порівняння відповідей на це запитання в регіональному вимірі увиразнило неоднорідність мовної ситуації в шкільній освіті за регіонами, а аналіз відповідей мешканців різних за чисельністю населених пунктів дав змогу простежити тенденції в подоланні нерівномірності мовного розвитку в державі за лінією “місто - село”.

Одне із запитань у групі F4 - Якою мовою Ви одержали середню освіту (варіанти відповіді: переважно украйнською, украӥнською і російською, переважно російською, важко відповісти) - дає можливість отримати інформацію про мовну ситуацію у сфері освіти в Україні впродовж років незалежності на підставі відповідей респондентів наймолодшої вікової групи (18-29 р.) і з певними застереженнями - групи 30 - 39 р. (респонденти цієї групи, якщо не цілком навчалися в українські школі, то принаймні закінчували іiі).

Решта запитань стосувалися мовної ситуації в освіті крізь призму можливих заходів держави в цій царині. Респондентам, зокрема, було запропоновано кілька запитань, які стосуються заходів мовної політики у сфері освіти, а саме: В4 - Як Ви вважаєте, чи обов'язковим $\epsilon$ викладання державною мовою в усіх державних закладах освіти? (варіанти відповіді-так, скоріше так, скоріше ні, ні, важко відповісти); В6 - Чи повинні викладачі (вчителі) спілкуватися державною мовою під час всього навчального прочесу (не тільки на лекціях чи уроках) в державних закладах освіти? (варіанти відповіді - так, скоріше так, скоріше ні, ні, важко відповісти); В5 - Чи обов 'язково в загальноосвітній школі вивчати як окремі дисципліни українську, російську, англійську чи іншу іноземну мови? (варіанти відповідей для кожної мови - так, ні, важко відповісти); у групі запитань F4 запитання Якою мовою Ви хотіли б, щзоб Ваші діти (майбутні діти) навчалися? (варіанти відповіді: переважно украӥнською, украӥнською і російською, переважно російською, важко відповісти); В9 - Як би Ви поставилися до законодавчого закріплення таких положень щуодо функціонування украӥнської мови як державної? (серед варіантів відповідей є твердження “Усі держслужбовиі, керівники навчальних та медичних 
закладів зобов 'язані вільно володіти українською мовою”) (варіанти відповіді - позитивно, скоріше позитивно, скоріше негативно, негативно, важко відповісти); В11 - На Вашу думку, держсавна політика в мовній сфері має перш за все сприяти поширенню үкраӥнської мови в усіх сферах, розв'язати питання щодо статусу російської мови, забезпечити реалізачію прав наиіональних меншин у мовній сфері?; В14 - Як Ви вважаєте, чи повинна російська мова мати на законодавчому рівні якісь переваги порівняно з мовами інших національних меншин, які мешкають на території Украӥни? (варіанти відповідей - так, ні, важко відповісти).

Державної мовної політики у сфері освіти стосується також запитання В7 - Як Ви вважаєте, чи потрібно запровадити іспит (атестацію) з украӥнської мови для всіх держслужбовців, для отримання громадянства Украӥни (варіанти відповідей для кожного варіанта - так, ні, важко відповісти), адже якщо держава вдається до такого заходу, то має бути передбачена система, яка дає змогу кожному громадянинові належно підготуватися до іспиту.

Утім, робити висновки про динаміку мовної ситуації у сфері освіти на підставі масового опитування можна тільки за умови порівняння його результатів із результатами інших досліджень, проведених за тією самою методикою. Уже йшлося про те, що дані нашого опитування надаються для порівняння з опитуванням, проведеним 2006 р. за програмою INTAS, у якому було поставлено запитання 1. Скільки людей, на Вашу думку, розмовляє украӥнською мовою в населеному пункті, де Ви мешкаєте, у школах? (варіанти відповіді: майже ніхто, значно менше половини, близько половини, значно більше половини, майже всі, важко відповісти); 2. Як Ви вважаєте, чи обов'язковим є викладання державною мовою в усіх державних закладах освіти? (варіанти відповіді - так, скоріме так, скоріме ні, ні, важко відповісти); 3. Чи повинні викладачі (вчителі) спілкуватися держсавною мовою під час всього навчального процесу (не тільки на лекціях чи уроках) в державних закладах освіти? (варіанти відповіді - так, скоріше так, скоріше ні, ні, важко відповісти); 4. Чи обов'язково в загальноосвітній школі вивчати як окремі дисципліни українську, російську, англійську чи іниу іноземну мови? (варіанти відповідей для кожної мови - так, ні, важко відповісти); 5. Як Ви вважаєте, чи потрібно запровадити іспит (атестацію) з української мови для всіх держслужбовців (варіанти відповідей - так, ні, важко відповісти) (Мовна політика та мовна ситуація в Україні, 2008).

Однакова методика, закладена в обох опитуваннях, дає змогу простежити залежність оцінки мовного середовища загальноосвітніх закладів від мовної ситуації в регіонах і від мовних преференцій інформантів, виявити зміни в настановах мовців щодо бажаних перспектив мовної освіти та заходів мовної політики в царині шкільної освіти, пов'язати оцінку мовного середовища шкіл респондентами зі змінами стереотипів суспільної свідомості, динамікою в питаннях престижу мов, коливаннями в оцінці заходів гуманітарного напряму внутрішньої політики, соціально-політичною ситуацією в країні тощо.

Висновки й перспективи подальших досліджень. Отже, масове опитування слугує надійним методом діагностування мовної ситуації в українській шкільній освіті, оскільки дає змогу простежити тенденції в різних сферах функціонування мови в масштабах усієї держави й пов'язати кількісні параметри мовної ситуації з якісними та оцінними. Саме масове опитування уможливлює об'єктивний аналіз деформацій мовної ситуації в Україні, успадкованих від радянської епохи. Таке дослідження пояснює, чому, попри високий ступінь формальної українізації (89,7 \% школярів навчаються українською мовою), система шкільної освіти не поклала край зросійщенню української молоді і не стала ефективним засобом зміцнення комунікативної потужності української мови. Результати, отримані на підставі аналізу даних масового опитування, є об’єктивними й достовірними, тож можуть слугувати надійним підгрунтям для випрацювання рекомендацій з гармонізації мовної ситуації в царині, найбільшою мірою орієнтованій на майбутнє. 


\footnotetext{
Примітки:

1 Частка учнів у школах України, що навчаються українською // http://statistika.in.ua/ mova2001/ukrainska v_shkolah\#

*Через хронічне запізнення із друком підручників на державне замовлення, недофінансування в деякі роки для українських шкіл $є$ типовою ситуація, коли діти не отримують нових підручників до жовтня - листопада, а часом і грудня поточного навчального року. За таких умов учителі користуються книжками з фонду шкільних бібліотек. Тож якщо школа мала статус навчального закладу з російською мовою викладання, то в ії бібліотеці зберігаються тільки відповідні підручники.
}

\section{ЛІТЕРАТУРА}

Івахнюк, О. (2017). У київській школі № 78 до украӥнської мови ставляться як до чогось неприємного $і$ в житті непотрібного. Взято $3 \mathrm{http}: / /$ novostiua.org/news/218147-u kijivsjkij_shkoli_78_do_ukrajinsjkoji_movi_stavljatjsja_jak_do_chogosj_neprijemnogo_i_v_hitti nepotribnogo.

Марусик, Т. (2017). Гібридна мовна політика Украӥни: між громадським вовком-санітаром i страусом-владою. Взято з https:/www.radiosvoboda.org/a/28892391.html.

Масенко, Л. Т. (2010). Нариси з соиіолінгвістики. Київ: Вид. Дім “Києво-Могилянська академія”. Масенко, Л. Т. (2016). Мовна політика Украӥни. Антиукраӥнський закон досі чинний. Взято 3 https://www.radiosvoboda.org/a/28025654.html.

Мовна політика та мовна ситуація в Україні: аналіз і рекомендації. (2008). Київ: Вид. Дім “КиєвоМогилянська академія".

Тараненко, О. О. (2009). Український і російський мовно-культурні вектори в сучасній Україні: реальність, політизація, міфи. Мовознавство, 2, 3-33.

\section{REFERENCES}

Ivakhniuk, O. (2017). U kyivs'kij shkoli № 78 do ukrains'koi movy stavliat'sia iak do chohos' nepryiemnoho i v zhytti nepotribnoho. Vziato z http://novostiua.org/nevs/218147-u_kiivsjkij_ shkoli_78_do_ukrainsjkoi_movi_stavliatjsia_iak_do_chogosj_neprijemnogo_i_v_hitti_nepotribnogo.

Marusyk, T. (2017). Hibrydna movna polityka Ukrainy: mizh hromads'kym vovkom-sanitarom i strausom-vladoiu. Vziato z https://vvv.radiosvoboda.org/a/28892391.html.

Masenko, L. T. (2010). Narysy z sotsiolinhvistyky. Kyiv: Vyd. Dim “Kyievo-Mohylians'ka akademiia”.

Masenko, L. T. (2016). Movna polityka Ukrainy. Antyukrains'kyj zakon dosi chynnyj. Vziato z https://vvv.radiosvoboda.org/a/28025654.html.

Movna polityka ta movna sytuatsiia v Ukraini: analiz i rekomendatsii. (2008). Kyiv: Vyd. Dim "Kyievo-Mohylians'ka akademiia".

Taranenko, O. O. (2009). Ukrains'kyj i rosijs'kyj movno-kul'turni vektory v suchasnij Ukraini: real'nist', polityzatsiia, mify. Movoznavstvo, 2, 3-33.

Дата надходження до редакиіï 23.03.2018 p. Ухвалено до друку 27.04.2018 p. 